\title{
Effects of Mangrove Zonation and the Physicochemical Parameters of Soil on the Distribution of Macrobenthic Fauna in Kadolkele Mangrove Forest, a Tropical Mangrove Forest in Sri Lanka
}

\author{
Navodha Dissanayake and Upali Chandrasekara \\ Department of Zoology \& Environmental Management, University of Kelaniya, 11600 Kelaniya, Sri Lanka \\ Correspondence should be addressed to Upali Chandrasekara; upali@kln.ac.lk
}

Received 21 August 2014; Accepted 17 November 2014; Published 16 December 2014

Academic Editor: Junbao Yu

Copyright (C) 2014 N. Dissanayake and U. Chandrasekara. This is an open access article distributed under the Creative Commons Attribution License, which permits unrestricted use, distribution, and reproduction in any medium, provided the original work is properly cited.

\begin{abstract}
The ecology of the macrobenthic fauna of the mangrove forests has received little attention compared to the mangrove flora. The present study was aimed at filling this information gap and investigated if the diversity and distribution of macrobenthic fauna at Kadolkele mangrove forest, a pristine mangrove forest situated at the Negombo estuary in Sri Lanka, are governed by the mangrove zonation and variation of physicochemical parameters of the mangrove soil. Since the aerial photographs identified three distinct mangrove zones at Kadolkele, namely, Rhizophora, Avicennia, and Lumnitzera zones, fauna were sampled and physicochemical parameters of the soil were measured in belt transects that were established at each mangrove zone. Data were collected and analyzed using appropriate field sampling techniques and statistical methods, respectively. Results revealed that the physicochemical parameters in soil varied between the three mangrove zones and that the distribution of benthic fauna followed the mangrove zonation. Further, the diversity measures of epifauna were found to be higher than those of the infauna of this tropical estuary.
\end{abstract}

\section{Introduction}

Mangroves are woody plants that grow at the interface between land and sea in tropical and subtropical latitudes where they exist in conditions of high salinity, extreme tides, strong winds, high temperature, and muddy anaerobic soils [1]. Mangrove forests provide shelter, food, and breeding sites for a large number of marine and terrestrial organisms [2] and are also important to humans for a variety of reasons, including fisheries, tourism, agriculture, forestry, protection against shoreline erosion, source of fire-wood and building material, and other local subsistence uses [1,3].

Mangrove forests can truly be considered as evolutionary hotspots where terrestrial species have readapted to marine life, and marine species have undergone the transition to terrestrial life [4]. The mangrove forest floors harbour a diverse and distinct assemblage of benthic organisms that range in size from the minute bacteria and protozoans to larger $(0.5 \mathrm{~mm}<$ size $)$ invertebrates termed as macrobenthos [5]. Kumar and Khan [6] emphasized that the distribution, abundance, and diversity of these mangrove benthic invertebrates and their relationships to environmental conditions are important parts of understanding the structure and function of mangrove ecosystems.

As a detritus based ecosystem, leaf litter from the mangroves provides the basis for adjacent aquatic and terrestrial food webs [7] where the macrobenthos typically occupy the second and third trophic levels [8]. Most of the macrobenthos assist in the breakdown of particulate organic matter by exposing them to microbes by shredding and their waste materials contain rich nutrients forming the food for other consumers. Alongi and Christoffersen [9] emphasized that the variations in the distribution and abundance of epibenthos of the mangrove area relate positively to variations in the quantity of exported detritus. 
Polychaetes, gastropods, and crustaceans are regarded to be the major macrobenthic organisms in the mangrove sediment. The distribution of macrobenthos may vary from habitat to habitat within the same mangrove forest. For example, a study carried out by Ellison [10] revealed that the density and the biomass of crabs and snails are higher in the young mangrove stands than in the intermediate aged stands of Rhizophoraceae. These macrobenthic organisms have a profound effect on the sedimentary environment, through their feeding, burrowing, and ventilatory activities.

Macrobenthic assemblage structure is influenced by local environmental conditions, such as hydroperiod, organic matter availability, and sediment characteristics [11]. Therefore the mangrove forest is considered to have physical, chemical, and biological processes which promote the adaptation of inhabiting organisms to tolerate greater amplitude of environmental characters both morphologically and physiologically [7].

Mangrove communities often exhibit distinct patterns of species distribution governed by the complexity of environmental factors $[12,13]$ and competition between individuals. The local patterns of tidal inundation influence soil characteristics that control species zonation of mangrove forests [12]. With the zonation of mangrove vegetation, invertebrates may often exhibit a marked zonation pattern and colonize a variety of specific microenvironments [7]. This zonation could take place either horizontally or vertically [14] where some species dwell on the sediment surface or reside in burrows while others live on pneumatophores and lower tree trunks or prop roots, burrow in decaying wood, or can even be found in the tree canopies [15].

Sedimentary characteristics in mangrove forests play a major role in structuring benthic communities in comparison to other physicochemical variables. According to Safahieh et al. [14] the distribution of macrobenthos is mainly determined by the sediment grain size, salinity, and availability of water. When there are extreme fluctuations in the physical features, then the abundance of benthic species may decline [1]. The spatial occurrence of these fauna is highly irregular, thus contributing to both the complexity and heterogeneity of the habitat [11]. The most successful benthic species of a mangrove forest are the ones who can easily adapt to the prevailing physical properties of that ecosystem.

Although there is a wealth of knowledge on the importance of mangroves on a global scale, information related to the ecology of the associated benthic fauna is scanty. As for the Kadolkele mangrove forest in Negombo estuary in Sri Lanka, the above is particularly true where a study carried out by Priyadarshani et al. [16] is perhaps the only detailed study focused on the mangrove faunal diversity, even though their study is confined only to the mangrove crabs. Yet the diversity and the distribution of macrobenthos existing in this mangrove forest floor are vast and have not been given due consideration. The present study was therefore designed and carried out to investigate some aspects of the ecology of macrobenthic fauna of the Kadolkele mangrove forest in relation to the mangrove zonation and physicochemical parameters of soil.

\section{Materials and Methods}

2.1. The Study Site. The present study was carried out at the Kadolkele mangrove forest $\left(7^{\circ} 11^{\prime} 49.82^{\prime \prime} \mathrm{N}, 79^{\circ} 50^{\prime} 32.29^{\prime \prime} \mathrm{E}\right)$ (Figure 1). It is situated at the northern extremity of the Negombo estuary of Sri Lanka and is a pristine and relatively undisturbed small mangrove forest patch that extends within an area of 10 ha [17]. It is also a popular site for mangrove related field studies [16].

The geographic region of the study area receives an average annual rainfall of $2400 \mathrm{~mm}$ and a monthly highest rainfall of $348 \mathrm{~mm}$ during October to November. The average temperature varies between $24^{\circ} \mathrm{C}$ and $30^{\circ} \mathrm{C}$ [18]. The Kadolkele mangrove forest contributes to a high productivity and hence supports the ecological balance of the adjacent Negombo estuarine ecosystem [19].

There is a great diversity of mangroves in the Kadolkele mangrove forest. According to Dahanayake and Sumanadasa [20], 29 mangrove species are found there and of those 18 are considered to be true mangroves. They also have recorded 33 other mangrove associated vegetation types. The highest abundance of mangroves is from the 3 mangrove families, namely, Rhizophoraceae, Avicenniaceae, and Combretaceae. The most abundant species from family Rhizophoraceae are Rhizophora apiculata and Rhizophora mucronata. Avicennia marina is the dominant species from family Avicenniaceae, while Lumnitzera racemosa is the most commonly found species in family Combretaceae in this mangrove forest [20].

There is a distinct mangrove zonation pattern in the Kadolkele mangrove forest (Figure 2). For example, a narrow mangrove zone, approximately $3 \mathrm{~m}$ in width, occupies at the estuary-land interface and is dominated by Rhizophora species. Avicennia species grow at the middle zone and the width of this zone is approximately $15 \mathrm{~m}$. Lumnitzera species are more abundant in the deeper areas of the mangrove forest where the width ranges from $50 \mathrm{~m}$ to $30 \mathrm{~m}$.

2.2. Field Sampling. Three belt transects, $40 \mathrm{~m}$ in length and $3 \mathrm{~m}$ width each, were established in the middle of each mangrove zone (Figure 2). The transects were demarcated by erecting coloured wooden posts at the four corners of each transect. Along each transect, 12 quadrat areas of $2 \mathrm{~m} \times 2 \mathrm{~m}$ were marked in a similar manner with a $2 \mathrm{~m}$ gap in between. The GPS locations of these transects were recorded separately using a portable Global Positioning System (Garmin-eTrex SUMMIT).

The number of mature mangrove trees, mangrove seedlings up to $1 \mathrm{~m}$ in height, and their pencil roots within each quadrat area were counted separately and recorded. The number of crab holes present in each quadrat were also counted and recorded. These crab holes were not dug for crabs due to logistic reasons. Therefore it was assumed that each crab hole is occupied by a single crab of the commonest crab species recorded previously in each mangrove zone by Priyadarshani et al. [16] and that the number of crab holes equals the number of crabs there.

The different species of epifauna on the mangrove forest floor and those who were sitting on the mangrove stems, seedlings, and pencil roots to a height of $0.5 \mathrm{~m}$ above 


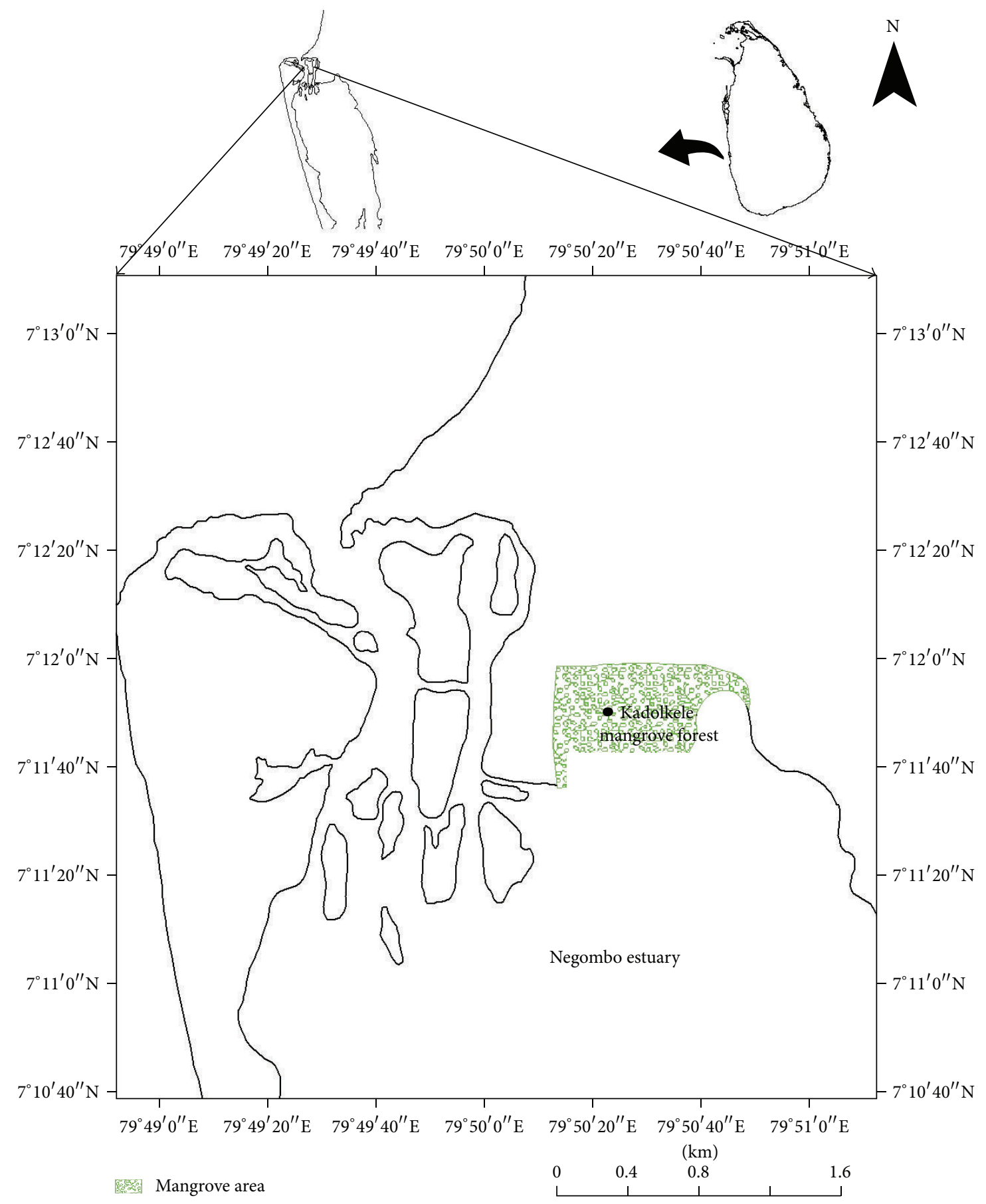

FIgURE 1: The map of Negombo estuary showing the Kadolkele mangrove forest. The location of Negombo estuary in the west coast of Sri Lanka is also shown.

the ground level within each quadrat area were carefully observed, counted separately, and recorded. These epifauna were identified in situ using standard field identification keys of Pinto [3] and Fernando [21]. Representative specimens of those who were counted but not identified at the site were collected, preserved in $5 \%$ formalin, and identified later at the laboratory.

Five soil samples were collected from within random locations of each quadrate to a depth of $15 \mathrm{~cm}$, each using a soil corer of $6 \mathrm{~cm}$ in diameter. These soil samples were wet sieved using a $0.5 \mathrm{~mm}$ sieve. The residues retained on the sieve were transferred into labeled polythene bags and preserved in a solution of $5 \%$ formaldehyde containing Rose Bengal. The fauna in each sample was separated, identified, and enumerated later at the laboratory.

Before the soil core samples were wet sieved, the approximate length of the black coloured soil Redox layer in each soil sample was measured in situ using a meter ruler. The soil penetrability from within 15 random locations of each quadrate area was also measured in situ following 


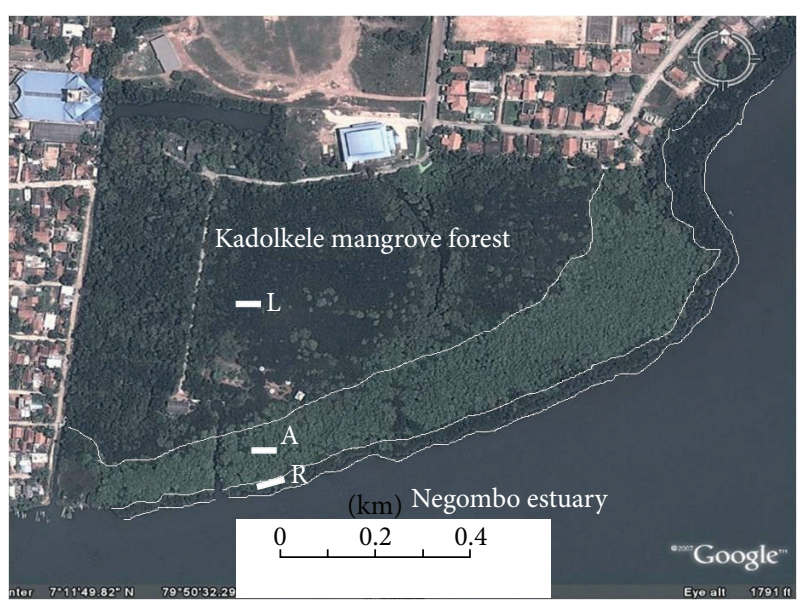

$\mathrm{R}=$ Rhizophora zone

$\mathrm{A}=$ Avicennia zone

$\mathrm{L}=$ Lumnitzera zone

Figure 2: Aerial photograph of the Kadolkele mangrove forest showing the distinct mangrove zonation. There are three mangrove zones in this mangrove forest: Rhizophora zone (R), Avicennia zone (A), and the Lumnitzera zone (L). Three belt transects, displayed as white rectangles on the photograph, were established along the center of each zone for sampling in the present study. The GPS locations of the Lumnitzera transect, Avicennia transect, and the Rhizophora transect were $7^{\circ} 19^{\prime} 55.94^{\prime \prime} \mathrm{N}, 79^{\circ} 84^{\prime} 41.01^{\prime \prime} \mathrm{E} ; 7^{\circ} 19^{\prime} 57.76^{\prime \prime} \mathrm{N}$, $79^{\circ} 84^{\prime} 40.03^{\prime \prime} \mathrm{E}$; and $7^{\circ} 19^{\prime} 61.14^{\prime \prime} \mathrm{N}, 79^{\circ} 84^{\prime} 38.03^{\prime \prime} \mathrm{E}$, respectively. Image source: Google Earth satellite maps.

the Bob James Pointy Stick method. In addition, 3 soil core samples, $6 \mathrm{~cm}$ in diameter and $15 \mathrm{~cm}$ deep each, were collected separately into labeled air tight sealed polythene bags for the determination of soil moisture content, organic matter content, $\mathrm{pH}$, salinity, conductivity, and particle size distribution later at the laboratory.

The study had many field visits that were carried out during the period of one and a half months starting from June to July 2013.

2.3. Laboratory Studies. After returning to the laboratory from each field visit, the soil moisture content, organic matter content, particle size distribution, $\mathrm{pH}$, conductivity, and salinity of the soil samples were determined separately using the methods described below.

The soil moisture content was determined by drying the moist soil samples in an oven at $105^{\circ} \mathrm{C}$ for 24 hours until a constant weight is gained. The organic matter content of these dried samples was determined by the dry combustion method described by Williams [22]. The particle size distribution was determined as approximate fraction of sand, silt, and humus using the method described by Brady and Weil [23].

The soil $\mathrm{pH}$ was measured using a digital $\mathrm{pH}$ meter (315i/SET) after making a soil suspension by adding distilled water into soil at 1:2 ratio following Jackson [24]. Electrical conductivity and salinity of soil were determined using a digital conductivity meter (Cond 340i/SET) by adding distilled water into soil at 1:5 ratio following Jackson [24].

In the meantime, the infauna sampled from the 3 mangrove zones and the epifauna that we did not identify at the field were identified to the nearest possible taxonomic category under the binocular microscope using the identification keys of Fernando and Mendis [25] and Fernando [21], Pillai [26], Quigley [27], Fauchald [28], Pinto [3], and Nesemann et al. [29] and enumerated separately.

2.4. Data Analysis. The total and percentage abundance of the infauna and epifauna recorded in the 3 mangrove zones were calculated separately. The abundance variation of the most dominant taxa between the 3 mangrove zones were analyzed by one-way ANOVA. When the ANOVA yielded a significant result, Tukey's pairwise comparison tests were carried out in a pairwise manner to test for significant differences between the 3 mangrove zones. The species richness (SR), Pielou's species evenness index $(J)$, and Shannon Wiener species heterogeneity index $\left(H^{\prime}\right)$ with respect to epifaunal and infaunal communities were calculated separately for each mangrove zone following the diversity indices described in Magurran [30].

The variation of soil $\mathrm{pH}$, conductivity, salinity, moisture content, organic matter content, sand $\%$, silt $\%$, clay $\%$, penetrability, and depth of the redox length layer between the 3 mangrove zones were analyzed by one-way ANOVA. When the ANOVA yielded a significant result, Tukey's pairwise comparison tests were carried out in a pairwise manner to test for significant differences between the 3 mangrove zones.

In order to identify the dominant macrobenthic fauna and sediment characteristics, the mean abundance values of the epifaunal taxa and the physicochemical parameters between the 3 zones were analyzed separately using the principal component analysis (PCA). Since there were only 2 dominant infaunal taxa, PCA was not carried out for the infaunal community.

There were more abundant as well as less abundant infaunal and epifaunal taxa recorded in the 3 mangrove zones. As the data analysis and result interpretation become extremely complex and complicated with these less abundant taxa, only the more abundant infaunal taxa (i.e., infauna with the total abundance of more than 97\%) and epifaunal taxa (i.e., epifauna with the total abundance of more than 90\%) were considered for the above PCA and one-way ANOVA following Melles et al. [31]. Finally, the relationships between the species richness, species heterogeneity, and species evenness of the infaunal community with the score set 1 of the PCA for physicochemical parameters of soil were analyzed separately using regression analysis. The data were analyzed using the statistical software packages of Minitab version 10.5 for Windows and Primer version 4.2 for Windows as appropriate at $\alpha=0.05$ level of significance.

\section{Results}

The Rhizophora zone and the Avicennia zone are dominated only by the mature trees, pencil roots, and the seedlings of 
Rhizophora and Avicennia species, respectively. No any other plant species was recorded from these two zones. The upper Lumnitzera zone is dominated mostly by the Lumnitzera mature trees and their seedlings (Table 1).

Altogether, 7 infaunal taxa belonging to 3 invertebrate phyla were recorded from the 3 mangrove zones (Table 2). These 7 taxa were Limnodrilus sp., Neanthes negomboensis, Dorylaimus stagnalis, Lembos sp., Holotrichia sp., Entomobryoides sp., and tabanid larvae. Of these 7 taxa, the most abundant was the Limnodrilus sp. (94.77\%), followed by $N$. negomboensis (2.82\%). Together, these 2 taxa accounted for more than $97 \%$ of the total infaunal abundance. Further the Limnodrilus sp. dominated at the Rhizophora and Lumnitzera zones with a relative abundance of $96 \%$ and $94.35 \%$, respectively. However there were no any infaunal taxa recorded from the middle Avicennia zone (Table 2).

The total abundance $(N)$, species richness (SR), species heterogeneity $\left(H^{\prime}\right)$, and species evenness $(J)$ of the infaunal community varied between the 3 zones (Table 3 ). As there were no any infaunal taxa in the middle Avicennia zone, the above diversity indices were " 0 " there. The total abundance, species richness, and species heterogeneity of the infaunal community were higher in the Lumnitzera zone than those in the Rhizophora zone. The infaunal community, however, was little more evenly distributed in the Rhizophora zone than in the Lumnitzera zone (Table 3).

In summary, there were many infaunal taxa in large numbers (i.e., high species richness and high total abundance) in the upper Lumnitzera zone so that the infaunal community is more diverse there (i.e., high species heterogeneity) than that in the lower Rhizophora zone.

Of the 2 dominant infaunal taxa, Limnodrilus sp. was significantly more abundant in the upper Lumnitzera zone than in the Rhizophora zone $(P<0.05$, Tukey's pairwise test after one-way ANOVA) (Table 4). Neanthes negomboensis was found in more or less similar numbers in both the Rhizophora and Lumnitzera zones $(P>0.05$, one-way ANOVA).

In addition to the above infaunal taxa, 11 other epibenthic taxa belonging to phylum Mollusca and phylum Arthropoda were also recorded from the 3 mangrove zones (Table 5). These 11 taxa were Cassidula nucleus, Melampus fasciatus, Clibanarius longitarsus, Episesarma versicolor, Sesarma guttatum, unidentified crab species, Sesarma smithii, Oecophylla smaragdina, Paratrechina longicornis, Solenopsis geminata, and Tetragnatha viridorufa. Of them, 6 epibenthic taxa, that is, C. nucleus (36.88\%), E. versicolor (3.48\%), S. guttatum (27.75\%), S. smithii (3.91\%), P. longicornis (7.20\%), and S. geminata $(14.11 \%)$, contributed to more than $90 \%$ of the total epibenthic abundance (Table 5).

As in the infaunal community, the total abundance $(N)$, species richness (SR), species heterogeneity $\left(H^{\prime}\right)$, and species evenness $(J)$ varied between the 3 mangrove zones (Table 6). Compared to the infaunal community, however, total abundance, species richness, and species heterogeneity of the epifaunal community were higher in the Rhizophora zone and higher than those in the Lumnitzera and Avicennia zones. The

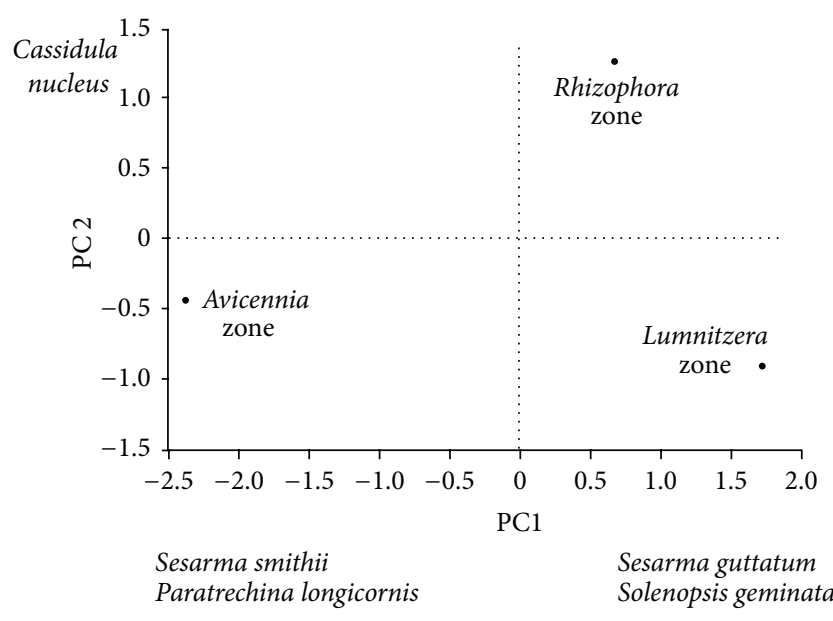

Figure 3: Ordination of the 3 mangrove zones based on the PC1 and PC2 scores of principal component analysis of the epifaunal community in Kadolkele mangrove forest (see also Table 7 for further details).

middle Avicennia zone recorded the highest species evenness than that of the other 2 zones (Table 6).

In summary, although there were many epifaunal individuals in the Lumnitzera zone (i.e., high total abundance), the epifaunal community there was dominated by one or a few taxa (low species richness and low species evenness). In the middle Avicennia zone, there were no dominating taxa and that the abundance of the existing taxa was more or less similar to each other (i.e., low species richness, high species heterogeneity, and high evenness). In the Rhizophora zone, however, there were many taxa (i.e., high species richness) with high number of individuals in each taxon/taxa (i.e., high species heterogeneity).

The most abundant epifaunal taxon characteristic to each mangrove zone is identified by the principal component analysis (PCA). According to the PCA analysis carried out for the 6 most abundant epifaunal taxa, the Lumnitzera zone, Avicennia zone, and Rhizophora zone were characterized by Sesarma guttatum, Sesarma smithii, and Cassidula nucleus (nucleus Cassidula snail), respectively (Figure 3). Further Lumnitzera and Avicennia zones are also characterized by Solenopsis geminata (red tropical fire ant) and Paratrechina longicornis (black ant), respectively.

The above PCA result was further endorsed by the oneway ANOVA carried out to test for the abundance of major epifaunal taxa between the 3 sites. A summary of the oneway ANOVA for the 3 mangrove zones is given in Table 8 . The abundance of Sesarma guttatum, Sesarma smithii, and Cassidula nucleus (nucleus Cassidula snail) was significantly high in the Lumnitzera zone, Avicennia zone, and Rhizophora zone, respectively $(P<0.05$, Tukey's pairwise test after oneway ANOVA). Episesarma versicolor (violet vinegar crab) and Paratrechina longicornis (black ant) were significantly abundant in the middle Avicennia zone $(P<0.05$, Tukey's pairwise test after one-way ANOVA).

Of the physicochemical parameters measured in the sediment, PCA analysis showed that the Rhizophora zone is 
TABLE 1: Summary of the vegetation structure of the 3 mangrove zones in Kadolkele mangrove forest, Negombo. Values are mean \pm SE and range in parenthesis ( $n=12$ quadrat samples from each mangrove zone).

\begin{tabular}{|c|c|c|c|}
\hline \multirow{2}{*}{ Vegetation structure } & \multicolumn{3}{|c|}{ Mangrove zone } \\
\hline & Rhizophora & Avicennia & Lumnitzera \\
\hline \multicolumn{4}{|l|}{ Rhizophora zone } \\
\hline Rhizophora mature trees & $\begin{array}{c}1.7 \pm 0.41 \\
(0-5)\end{array}$ & 0 & 0 \\
\hline Rhizophora seedlings & $\begin{array}{c}9.5 \pm 1.64 \\
(2-21)\end{array}$ & 0 & 0 \\
\hline Rhizophora pencil roots & $\begin{array}{c}65.4 \pm 12.70 \\
(16-179)\end{array}$ & 0 & 0 \\
\hline \multicolumn{4}{|l|}{ Avicennia zone } \\
\hline Avicennia mature trees & 0 & $\begin{array}{c}0.75 \pm 0.13 \\
(0-1)\end{array}$ & 0 \\
\hline Avicennia seedlings & 0 & $\begin{array}{c}29.33 \pm 5.79 \\
(0-62)\end{array}$ & 0 \\
\hline Avicennia pencil roots & 0 & $\begin{array}{c}359 \pm 30.60 \\
(215-538)\end{array}$ & 0 \\
\hline \multicolumn{4}{|l|}{ Lumnitzera zone } \\
\hline Lumnitzera mature trees & $\begin{array}{c}0.08 \pm 0.08 \\
(0-1)\end{array}$ & 0 & $\begin{array}{c}4.17 \pm 0.64 \\
(1-8)\end{array}$ \\
\hline Lumnitzera seedlings & 0 & 0 & $\begin{array}{c}0.17 \pm 0.17 \\
\quad(0-2)\end{array}$ \\
\hline Lumnitzera pencil roots & 0 & 0 & $\mathbf{0}$ \\
\hline
\end{tabular}

TABLE 2: The relative abundance of the infaunal taxa recorded from the 3 mangrove zones in Kadolkele mangrove forest $(n=60$ soil core samples from each mangrove zone).

\begin{tabular}{|c|c|c|c|c|c|c|c|}
\hline \multirow{3}{*}{ Phylum } & \multirow{3}{*}{ Family } & \multirow{3}{*}{ Genus/species } & \multicolumn{3}{|c|}{ Total abundance in each zone and } & \multirow{3}{*}{$\begin{array}{l}\text { Total abundance } \\
\text { all } 3 \text { zones }\end{array}$} & \multirow{3}{*}{$\begin{array}{c}\text { Relative } \\
\text { abundance } \\
(\%)\end{array}$} \\
\hline & & & \multicolumn{3}{|c|}{ relative abundance (\%) in parenthesis } & & \\
\hline & & & $\begin{array}{l}\text { Rhizophora } \\
\text { zone }\end{array}$ & $\begin{array}{l}\text { Avicennia } \\
\text { zone }\end{array}$ & $\begin{array}{c}\text { Lumnitzera } \\
\text { zone }\end{array}$ & & \\
\hline \multirow{2}{*}{ Annelida } & Tubificidae & $\begin{array}{c}\text { Limnodrilus sp. } \\
\text { (oligochaete worms) }\end{array}$ & $120(96)$ & $0(0)$ & $351(94.35)$ & 471 & 94.77 \\
\hline & Nereididae & $\begin{array}{c}\text { Neanthes negomboensis } \\
\text { (polychaete worm) }\end{array}$ & $4(3.2)$ & $0(0)$ & $10(2.69)$ & 14 & 2.82 \\
\hline \multirow[t]{3}{*}{ Nematoda } & Dorylaimida & $\begin{array}{l}\text { Dorylaimus stagnalis } \\
\text { (round worm) }\end{array}$ & $0(0)$ & $0(0)$ & $2(0.54)$ & 2 & 0.40 \\
\hline & Aoridae & Lembos sp. (amphipod) & $0(0)$ & $0(0)$ & $6(1.61)$ & 6 & 1.21 \\
\hline & Scarabaeidae & Holotrichia sp. (white grub) & $0(0)$ & $0(0)$ & $1(0.27)$ & 1 & 0.20 \\
\hline \multirow[t]{4}{*}{ Arthropoda } & Entomobryidae & $\begin{array}{l}\text { Entomobryoides sp. } \\
\text { (slender springtail) }\end{array}$ & $1(0.8)$ & $0(0)$ & $1(0.27)$ & 2 & 0.40 \\
\hline & Tabanidae & $\begin{array}{l}\text { Tabanid larvae } \\
\text { (horse fly larvae) }\end{array}$ & $0(0)$ & $0(0)$ & $1(0.27)$ & 1 & 0.20 \\
\hline & \multicolumn{2}{|c|}{ Species richness } & 3 & $\mathbf{0}$ & 7 & & \\
\hline & \multicolumn{2}{|c|}{ Total abundance of infauna } & 125 & $\mathbf{0}$ & 372 & 497 & 100 \\
\hline
\end{tabular}

characterized by the higher depth of redox layer, high $\mathrm{pH}$, and high sand, silt, and clay percentages while the upper Lumnitzera zone is characterized by high $\mathrm{pH}$, high clay \%, and high penetrability of soil. The soil moisture content, organic matter content, conductivity, salinity, and penetrability were high in the middle Avicennia zone (Figure 4).
A summary of the ANOVA and variation of the physicochemical parameters between the 3 mangrove zones is given in Table 10. Almost all these parameters varied either significantly or not significantly between the 3 mangrove zones. This ANOVA endorsed most of the above PCA analysis (Figure 4) (Table 9). For example, the depth of the redox layer, 
TABLE 3: Variation of the total abundance $(N)$, species richness (SR), species heterogeneity $\left(H^{\prime}\right)$, and species evenness $(J)$ of the infaunal community between the 3 mangrove zones in Kadolkele mangrove forest ( $n=60$ soil core samples in each zone).

\begin{tabular}{lccc}
\hline $\begin{array}{l}\text { Measure of the infaunal } \\
\text { diversity }\end{array}$ & $\begin{array}{c}\text { Rhizophora } \\
\text { zone }\end{array}$ & $\begin{array}{c}\text { Avicennia } \\
\text { zone }\end{array}$ & $\begin{array}{c}\text { Lumnitzera } \\
\text { zone }\end{array}$ \\
\hline $\begin{array}{l}\text { Total abundance }(N) \\
\text { Species richness (SR) }\end{array}$ & 125 & 0 & 372 \\
$\begin{array}{l}\text { Species heterogeneity } \\
\left(H^{\prime}\right)\end{array}$ & 0.19 & 0 & 7 \\
Species evenness $(J)$ & 0.17 & $\infty$ & 0.29 \\
\hline
\end{tabular}

TABLE 4: Summary of the 2 major infaunal taxa that contributed to more than $97 \%$ of the total species abundance of the 3 mangrove zones in Kadolkele mangrove forest ( $n=60$ soil core samples from each zone).

\begin{tabular}{lccc}
\hline Infauna taxa & $\begin{array}{c}\text { Rhizophora } \\
\text { zone }\end{array}$ & $\begin{array}{c}\text { Avicennia } \\
\text { zone }\end{array}$ & $\begin{array}{c}\text { Lumnitzera } \\
\text { zone }\end{array}$ \\
\hline $\begin{array}{l}\text { Limnodrilus sp. }^{*} \\
\text { (oligochaete worms) }^{2.00 \pm 0.40^{\mathrm{a}}} \\
(0-16)\end{array}$ & $0^{\mathrm{b}}$ & $\begin{array}{c}5.85 \pm 0.95^{\mathrm{c}} \\
(0-29)\end{array}$ \\
$\begin{array}{l}\text { Neanthes negomboensis } \\
\text { (polychaete worm) }\end{array}$ & $\begin{array}{c}0.07 \pm 0.03^{\mathrm{a}, \mathrm{b}} \\
(0-1)\end{array}$ & $0^{\mathrm{a}}$ & $\begin{array}{c}0.17 \pm 0.05^{\mathrm{b}} \\
(0-2)\end{array}$ \\
\hline
\end{tabular}

Note. Values are mean \pm SE, range in parenthesis. Different superscript letters in a row denote significant differences $(P<0.05)$ indicated by Tukey's pairwise significant difference test. * indicates significantly calculated $P$ value detected by ANOVA.

clay $\%$, and $\mathrm{pH}$ were significantly high in the Rhizophora zone $(P<0.05$, Tukey's pairwise test after one-way ANOVA). The soil moisture content, organic matter content, and soil penetrability were significantly high in the middle Avicennia zone $(P<0.05$, Tukey's pairwise test after one-way ANOVA). Further, soil $\mathrm{pH}$, penetrability, and clay \% were significantly high in the upper Lumnitzera zone $(P<0.05$, Tukey's pairwise test after one-way ANOVA).

Although not significant, the total abundance, species richness, and species heterogeneity increased with the increasing depth of the redox layer, $\mathrm{pH}$, clay $\%$, silt $\%$, and sand \% of the sediment $(P>0.05$, regression analysis $)$ (Figures 5, 6, and 7) while the species evenness increased significantly with the same $(P<0.05$, regression analysis $)$ (Figure 8).

\section{Discussion}

The present study was carried out to investigate the mangrove zonation and the way in which the physicochemical parameters of the sedimentary environment affect the distribution and diversity of macrobenthic fauna in the Kadolkele mangrove forest in Negombo estuary. The study initially revealed that there is a distinct mangrove zonation in this mangrove forest, where Rhizophora sp. occupied the estuarine water frontage; Lumnitzera sp. occupied the landward side while Avicennia sp. dominated in between the above 2 zones. A study by Jayakody et al. [32] has also shown a similar mangrove zonation in Kadolkele mangrove forest.

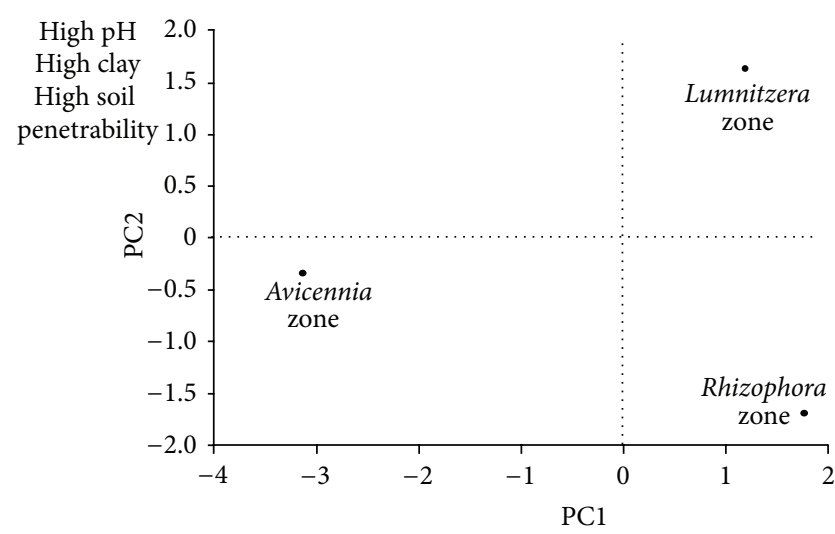

High soil moisture content High organic matter content High conductivity High salinity High soil penetrability

High length of redox layer High clay (\%) High sand (\%) High silt (\%)

Figure 4: Ordination of the 3 mangrove zones based on PC1 and PC2 scores of PCA of the physicochemical parameters of soil in Kadolkele mangrove forest. Rhizophora zone is characterized by the higher depth of redox layer, high $\mathrm{pH}$, and high sand, silt, and clay percentages while upper Lumnitzera zone is characterized by high $\mathrm{pH}$, high clay $\%$, and high penetrability of soil. The soil moisture content, organic matter content conductivity, salinity, and penetrability are high in the middle Avicennia zone (see also Table 9 for further details).

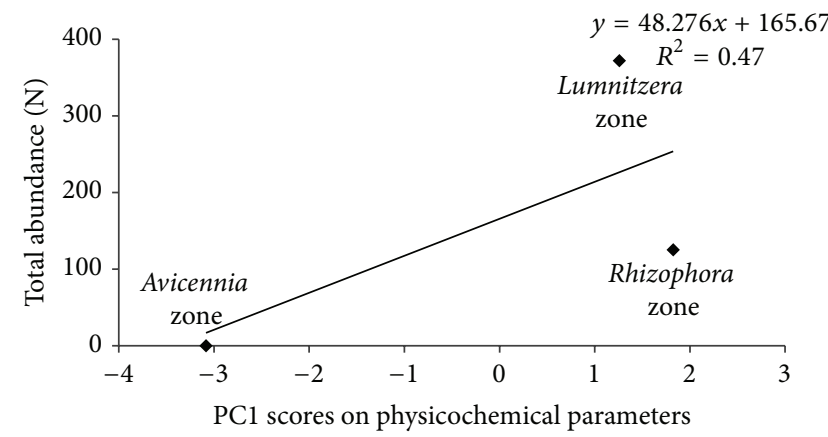

High soil moisture

High organic matter

High conductivity

High salinity

High penetrability
High pH

High redox length

High clay (\%)

High sand (\%)

High silt (\%)
FIGURE 5: The relationship between the total abundance of infaunal community and PC1 scores for physicochemical characteristics of soil in the 3 mangrove zones in Kadolkele mangrove forest.

In spite of the understanding of ecological, economic, and social importance of the Kadolkele mangrove forest [3236] little is known about the ecology of its macrobenthic fauna. Therefore the present study was designed focusing on some aspects of the ecology of these macrobenthic fauna and showed that they exhibited a distinct variation in parallel to the variation of physicochemical parameters of soil between the 3 mangrove zones there. 
TABLE 5: The total and relative abundance of the epifaunal taxa recorded from the 3 mangrove zones in Kadolkele mangrove forest $(n=12$ quadrate samples from each mangrove zone).

\begin{tabular}{|c|c|c|c|c|c|c|}
\hline \multirow{3}{*}{ Phylum } & \multirow{3}{*}{ Genus/species } & \multicolumn{3}{|c|}{ Total abundance in each zone } & \multirow{3}{*}{$\begin{array}{l}\text { Total abundance } \\
\text { ( } 3 \text { zones })\end{array}$} & \multirow{3}{*}{$\begin{array}{c}\text { Relative } \\
\text { abundance } \\
(\%)\end{array}$} \\
\hline & & \multicolumn{3}{|c|}{ Relative abundance (\%) in parenthesis } & & \\
\hline & & $\begin{array}{l}\text { Rhizophora } \\
\text { zone }\end{array}$ & $\begin{array}{l}\text { Avicennia } \\
\text { zone }\end{array}$ & $\begin{array}{l}\text { Lumnitzera } \\
\text { zone }\end{array}$ & & \\
\hline \multirow{2}{*}{ Mollusca } & $\begin{array}{c}\text { Cassidula nucleus } \\
\text { (nucleus Cassidula snail) }\end{array}$ & $784(69.81)$ & $0(0.00)$ & $0(0.00)$ & 784 & 36.88 \\
\hline & $\begin{array}{c}\text { Melampus fasciatus } \\
\text { (banded melampus snail) }\end{array}$ & $50(4.45)$ & $0(0.00)$ & $0(0.00)$ & 50 & 2.35 \\
\hline \multirow{9}{*}{ Arthropoda } & $\begin{array}{l}\text { Clibanarius longitarsus } \\
\text { (hermit crab) }\end{array}$ & $17(1.51)$ & $0(0.00)$ & $0(0.00)$ & 17 & 0.80 \\
\hline & $\begin{array}{l}\text { Episesarma versicolor } \\
\text { (violet vinegar crab) }\end{array}$ & $22(1.96)$ & $52(20.23)$ & $0(0.00)$ & 74 & 3.48 \\
\hline & Sesarma guttatum & $18(1.60)$ & $0(0.00)$ & $572(76.68)$ & 590 & 27.75 \\
\hline & Unidentified crab species & $22(1.97)$ & $0(0.00)$ & $0(0.00)$ & 22 & 1.03 \\
\hline & Sesarma smithii & $0(0.00)$ & $83(32.3)$ & $0(0.00)$ & 83 & 3.91 \\
\hline & Oecophylla smaragdina (dimiya) & $49(4.36)$ & $0(0.00)$ & $0(0.00)$ & 49 & 2.30 \\
\hline & $\begin{array}{l}\text { Paratrechina longicornis } \\
\text { (black ant) }\end{array}$ & $26(2.32)$ & $116(45.14)$ & $11(1.47)$ & 153 & 7.20 \\
\hline & $\begin{array}{l}\text { Solenopsis geminata } \\
\text { (Red tropical fire ant) }\end{array}$ & $133(11.84)$ & $5(1.94)$ & $162(21.72)$ & 300 & 14.11 \\
\hline & $\begin{array}{l}\text { Tetragnatha viridorufa } \\
\text { (common long jawed orb weaver) }\end{array}$ & $2(0.18)$ & $1(0.39)$ & $1(0.13)$ & 4 & 0.19 \\
\hline & Species richness & 10 & 5 & 3 & & \\
\hline \multicolumn{2}{|c|}{ Total abundance of epifauna } & 1123 & 257 & 746 & 2126 & 100 \\
\hline
\end{tabular}

TABLE 6: Variation of the total abundance $(N)$, species richness (SR), species heterogeneity $\left(H^{\prime}\right)$, and species evenness $(J)$ of epifaunal community between the 3 mangrove zones in Kadolkele mangrove forest ( $n=12$ quadrat samples from each zone).

\begin{tabular}{lccc}
\hline $\begin{array}{l}\text { Measure of the epifaunal } \\
\text { diversity }\end{array}$ & $\begin{array}{c}\text { Rhizophora } \\
\text { zone }\end{array}$ & $\begin{array}{c}\text { Avicennia } \\
\text { zone }\end{array}$ & $\begin{array}{c}\text { Lumnitzera } \\
\text { zone }\end{array}$ \\
\hline $\begin{array}{l}\text { Total abundance }(N) \\
\text { Species richness (SR) }\end{array}$ & 1123 & 257 & 746 \\
$\begin{array}{l}\text { Species heterogeneity } \\
\left(H^{\prime}\right)\end{array}$ & 10 & 5 & 4 \\
Species evenness $(J)$ & 0.5 & 1.15 & 0.61 \\
\hline
\end{tabular}

Mangrove soils are typically saline, anoxic, acidic, and frequently waterlogged. These soil properties directly affect the distribution and condition of the mangrove forests [2, 12]. Starting from the margin of the Negombo estuary (i.e., Rhizophora zone) towards more landward side (i.e., Lumnitzera zone) in the Kadolkele mangrove forest, it was found that the soil moisture content, salinity, conductivity, sand $\%$, and length of redox layer decreased while the soil $\mathrm{pH}$, organic matter content, soil surface penetrability, silt $\%$, and clay $\%$ increased. This is the general pattern in almost all the mangrove forests in the world [1].

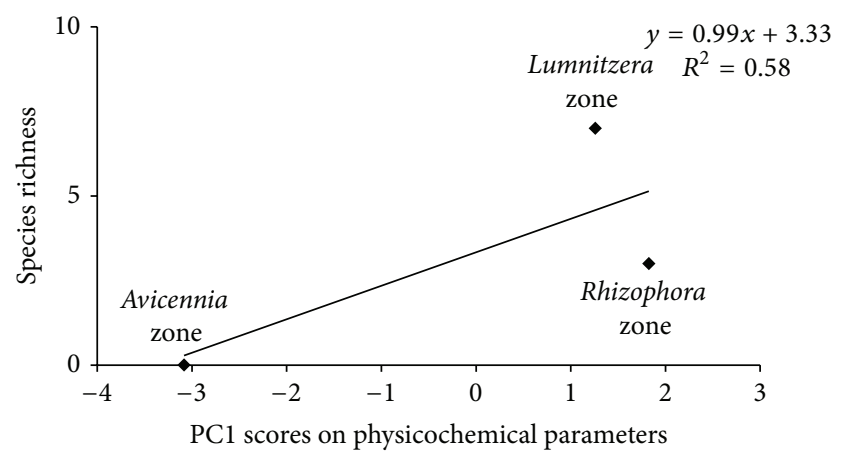

High soil moisture High organic matter High conductivity High salinity High penetrability High $\mathrm{pH}$ High redox length High clay (\%) High sand (\%) High silt (\%)

FIGURE 6: The relationship between the species richness of the infaunal community and PC1 scores for physicochemical characteristics of soil in the 3 mangrove zones in Kadolkele mangrove forest.

The soil/sediment in the Rhizophora zone registered comparatively high moisture content and was found that the sediment is mostly wet. Owing to the fact that the Rhizophora zone experiences the tidal inundation with $\mathrm{O}_{2}$ saturated 
TABLE 7: Summary of the eigenvalues, eigenvectors, and PCA scores of the epifaunal community of the 3 mangrove zones in Kadolkele mangrove forest.

\begin{tabular}{|c|c|c|c|}
\hline \multicolumn{4}{|c|}{ Eigenvalues } \\
\hline PC & Eigenvalues & \%Variation & Cum. \%variation \\
\hline 1 & 4.47 & 74.6 & 74.6 \\
\hline 2 & 1.53 & 25.4 & 100.0 \\
\hline \multicolumn{4}{|c|}{ Eigenvectors } \\
\hline Variable & $\mathrm{PC} 1$ & PC2 & \\
\hline Cassidula nucleus (Nuclues Cassidula snail) & 0.129 & 0.779 & \\
\hline Sesarma smithii & -0.458 & -0.197 & \\
\hline Episesarma versicolor (Violet vinegar crab) & -0.464 & 0.152 & \\
\hline Sesarma guttatum & 0.338 & -0.565 & \\
\hline Paratrechina longicornis (Black Ant) & -0.470 & -0.092 & \\
\hline Solenopsis geminata (Red tropical fire ant) & 0.472 & 0.058 & \\
\hline \multicolumn{4}{|c|}{ Principal component scores } \\
\hline Sample & Score 1 & Score 2 & \\
\hline Rhizophora zone & 0.669 & 1.372 & \\
\hline Avicennia zone & -2.369 & -0.348 & \\
\hline Lumnitzera zone & 1.700 & -1.024 & \\
\hline
\end{tabular}

TABLE 8: Summary of the 6 major epifaunal taxa that contributed to more than $90 \%$ of the total species abundance in the 3 mangrove zones in Kadolkele mangrove forest ( $n=12$ quadrate samples from each zone).

\begin{tabular}{|c|c|c|c|}
\hline Epifauna species & Rhizophora zone & Avicennia zone & Lumnitzera zone \\
\hline Cassidula nucleus* & $\begin{array}{c}65.30 \pm 13.60^{\mathrm{a}} \\
(5-158)\end{array}$ & $0^{\mathrm{b}}$ & $0^{\mathrm{b}}$ \\
\hline $\begin{array}{l}\text { Episesarma versicolor } \\
\text { (violet vinegar crab) }\end{array}$ & $\begin{array}{l}1.83 \pm 0.89^{\mathrm{a}} \\
\quad(0-10)\end{array}$ & $\begin{array}{c}4.33 \pm 1.50^{\mathrm{a}} \\
\quad(0-20)\end{array}$ & $0^{\mathrm{b}}$ \\
\hline Sesarma guttatum ${ }^{*}$ & $\begin{array}{c}1.50 \pm 0.73^{\mathrm{a}} \\
\quad(0-8)\end{array}$ & $0^{\mathrm{a}}$ & $\begin{array}{c}47.67 \pm 4.24^{\mathrm{b}} \\
(24-76)\end{array}$ \\
\hline Sesarma smithii ${ }^{*}$ & $0^{\mathrm{a}}$ & $\begin{array}{c}6.92 \pm 0.87^{b} \\
(3-12)\end{array}$ & $0^{\mathrm{a}}$ \\
\hline $\begin{array}{l}\text { Paratrechina longicornis } \\
\text { (black ant) }\end{array}$ & $\begin{array}{l}2.17 \pm 0.10 \\
\quad(0-10)\end{array}$ & $\begin{array}{l}9.67 \pm 8.52 \\
\quad(0-103)\end{array}$ & $\begin{array}{l}0.92 \pm 0.54 \\
\quad(0-6)\end{array}$ \\
\hline $\begin{array}{l}\text { Solenopsis geminata } \\
\text { (red tropical fire ant) }\end{array}$ & $\begin{array}{l}11.08 \pm 6.12 \\
\quad(0-76)\end{array}$ & $\begin{array}{l}0.42 \pm 0.34 \\
\quad(0-4)\end{array}$ & $\begin{array}{c}13.50 \pm 5.47 \\
(0-54)\end{array}$ \\
\hline
\end{tabular}

Note. Values are mean \pm SE, range in parenthesis. Different superscript letters in a row denote significant differences $(P<0.05)$ indicated by Tukey's pairwise significant difference test. * indicates significantly calculated $P$ value detected by ANOVA.

estuarine water twice a day causes to increase the moisture content in the soil of this zone. This zone also contained a high amount of sand and silt. When the sand percentage increases, the pore spaces are also increased [37] so that the oxygen rich water seeps in creating oxidized condition in soil. This $\mathrm{O}_{2}$ rich moist soil leads to high rate of aerobic microbial decomposition in this zone and makes the depth of its redox layer more wider than those in the other two zones.

During the study period, a frequent water logged condition was observed in the middle Avicennia zone. It is noteworthy that the ground level of this zone is a little lower and depressed than in the Rhizophora and Lumnitzera zones. The slow watershed thus resulting in this zone leads the tide water as well as the rain water to retain for a longer time. This was further proven by the presence of very high percentage of soil moisture in this zone. The soil organic matter content of this zone was also significantly high, compared to the other two zones perhaps as a result of the continuous accumulation of organic matter in this zone due to poor watershed. Further, this zone recorded the highest density of pencil roots and the lowest depth of redox layer in soil. It is therefore evident that the soil in this zone is water logged and in highly reduced $\mathrm{O}_{2}$ poor anoxic state (i.e., lowest depth of redox layer). The low $\mathrm{O}_{2}$ concentration decreases the aerobic decomposition of organic matter and promotes anaerobic decomposition [38] and produces gases such as $\mathrm{H}_{2} \mathrm{~S}$. During the study it was noticed that this zone is doused with a pungent smell of rotten eggs indicating the anaerobic decomposition and production and presence of gaseous $\mathrm{H}_{2} \mathrm{~S}$. By contrast, the soil in the upper Lumnitzera zone has a high clay percentage and that the soil 


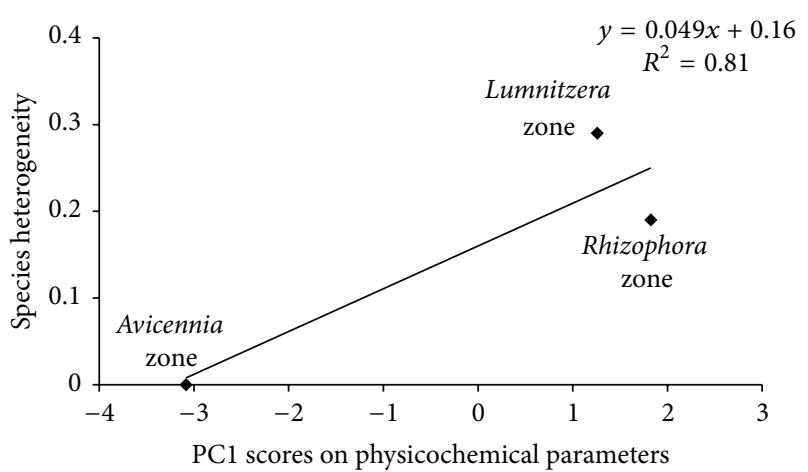

$\begin{array}{ll}\text { High soil moisture } & \text { High } \mathrm{pH} \\ \text { High organic matter } & \text { High redox length } \\ \text { High conductivity } & \text { High clay }(\%) \\ \text { High salinity } & \text { High sand (\%) } \\ \text { High penetrability } & \text { High silt (\%) }\end{array}$

FIGURE 7: The relationship between the species heterogeneity of the infaunal community and PC1 scores for physicochemical characteristics of soil in the 3 mangrove zones in Kadolkele mangrove forest.

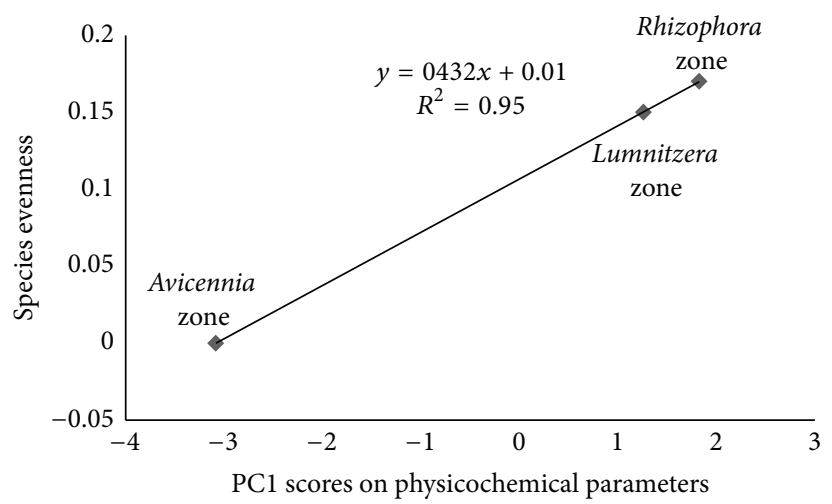

High soil moisture High organic matter High conductivity High salinity High penetrability

High $\mathrm{pH}$ High redox length High clay (\%) High sand (\%) High silt (\%)

FIGURE 8: The relationship between the species evenness of the infaunal community and $\mathrm{PC} 1$ scores for physicochemical characteristics of soil in the 3 mangrove zones in Kadolkele mangrove forest.

$\mathrm{pH}$ was neutral compared to the other two zones. Further, the absence of aerial roots is a good evidence of having a well-aerated drained soil in this zone. This zone is also far from the estuary margin and receives water mostly from rain. Therefore the soil salinity is also low as shown in the present study.

Apart from the availability of particulate organic matter, efficient provision of oxygen to soil could also be a reason for the increased numbers of the Limnodrilus sp. particularly in the landward Lumnitzera zone. This is made possible by the large number of crab holes present in this zone. Under ground, these crab holes are interconnected so that there is a good supply of oxygen to a deeper area of the inner soil. Lee [11] found that the burrowing macrofauna
TABLE 9: Summary of the eigenvalues, eigenvectors, and PCA scores of the physicochemical parameters in soil of the 3 mangrove zones in Kadolkele mangrove forest.

\begin{tabular}{|c|c|c|c|}
\hline \multicolumn{4}{|c|}{ Eigenvalues } \\
\hline PC & Eigenvalues & \%Variation & Cum. \%variation \\
\hline 1 & 7.21 & 72.1 & 72.1 \\
\hline 2 & 2.79 & 27.9 & 100.0 \\
\hline \multicolumn{4}{|c|}{ Eigenvectors } \\
\hline Variable & $\mathrm{PC} 1$ & PC2 & \\
\hline Soil moisture (\%) & -0.367 & -0.103 & \\
\hline Soil organic matter $(\%)$ & -0.371 & -0.059 & \\
\hline Soil pH & 0.325 & 0.292 & \\
\hline Conductivity (mS/cm) & -0.339 & -0.247 & \\
\hline Salinity & -0.350 & -0.204 & \\
\hline Penetrability $(\mathrm{cm})$ & -0.301 & 0.353 & \\
\hline Redox length (cm) & 0.305 & -0.345 & \\
\hline Sand \% & 0.262 & -0.426 & \\
\hline Silt \% & 0.102 & -0.576 & \\
\hline Clay \% & 0.350 & 0.204 & \\
\hline \multicolumn{4}{|c|}{ Principal component scores } \\
\hline Sample & Score 1 & Score 2 & \\
\hline Rhizophora zone & 1.825 & -1.559 & \\
\hline Avicennia zone & -3.084 & -0.203 & \\
\hline Lumnitzera zone & 1.259 & 1.761 & \\
\hline
\end{tabular}

increase the surface area of the sediment-air-water interface so that $\mathrm{O}_{2}$ diffusion to soil is facilitated. Although this $\mathrm{O}_{2}$ enrichment to soil could have been proven experimentally in the present study too, it was not taken into consideration at the initial stage of the experimental design. Therefore, measuring sediment $\mathrm{O}_{2}$ level in future studies that address the ecology and distribution of benthic fauna is recommended.

The physicochemical parameters of soil in both $R h i$ zophora and Lumnitzera zones varied within a wide range. Since Limnodrillus sp. is abundant in both zones, it suggests that this species has a wide tolerance range with respect to the physicochemical parameters measured in this study. Yap et al. [39] have recorded Limnodrilus sp. as a species of pollution indicator that can tolerate excessive levels of nutrient concentrations, low levels of oxygen, and $\mathrm{pH}$. The water logged condition creating hyperanoxic conditions might have led to absence of any other infauna other than Limnodrilus sp. in the middle Avicennia zone. A study carried out by Thilagavathi et al. [7] has shown a similar situation in a mangrove sedimentary environment in Tamilnadu in India where extreme conditions including anoxic conditions in the mangrove sediment lower the abundance of less tolerant infaunal species.

The primary productivity of mangroves is considered to be one of the highest in the world [38], but a large portion of it has been left unconsumed and accumulated within the mangrove system [11]. Thereafter physical and microbial decomposition begin depleting the available oxygen leading to hypoxic or anoxic soil conditions [7]. This is perhaps the case with the middle Avicennia zone where there was low 
TABLE 10: Summary of the physicochemical parameters of soil between the 3 mangrove zones in Kadolkele mangrove forest $(n=18)$.

\begin{tabular}{|c|c|c|c|}
\hline Physicochemical parameter in soil & Rhizophora zone & Avicennia zone & Lumnitzera zone \\
\hline \multirow{2}{*}{$\mathrm{pH}^{*}$} & $6.45 \pm 0.26^{\mathrm{a}}$ & $5.09 \pm 0.20^{\mathrm{b}}$ & $7.34 \pm 0.15^{\mathrm{c}}$ \\
\hline & $(4.22-7.70)$ & $(3.58-7.89)$ & $(6.52-8.14)$ \\
\hline \multirow{2}{*}{ Conductivity $(\mathrm{mS} / \mathrm{cm})^{*}$} & $1.57 \pm 0.11^{\mathrm{a}}$ & $2.20 \pm 0.22^{\mathrm{b}}$ & $1.27 \pm 0.10^{\mathrm{a}}$ \\
\hline & $(0.778-2.35)$ & $(0.835-3.88)$ & $(0.65-2.17)$ \\
\hline \multirow{2}{*}{ Salinity $(\mathrm{ppt})^{*}$} & $0.57 \pm 0.06^{\mathrm{a}}$ & $0.99 \pm 0.13^{\mathrm{b}}$ & $0.43 \pm 0.06^{\mathrm{a}}$ \\
\hline & $(0.10-1.00)$ & $(0.20-2.00)$ & $(0.10-1.0)$ \\
\hline \multirow{2}{*}{ Moisture content $(\%)^{*}$} & $29.23 \pm 2.13^{\mathrm{a}}$ & $44.02 \pm 2.66^{b}$ & $28.03 \pm 0.66^{\mathrm{a}}$ \\
\hline & $(10.9-47.13)$ & $(24.92-68.28)$ & $(22.77-32.19)$ \\
\hline \multirow{2}{*}{ Organic matter content $(\%)^{*}$} & $4.59 \pm 0.51^{\mathrm{a}}$ & $19.72 \pm 3.40^{\mathrm{b}}$ & $4.72 \pm 0.20^{\mathrm{a}}$ \\
\hline & $(1.99-9.15)$ & $(4.42-54.05)$ & $(2.75-6.02)$ \\
\hline \multirow{2}{*}{ Sand \% } & $61.02 \pm 3.96$ & $52.89 \pm 2.55$ & $54.21 \pm 1.11$ \\
\hline & $(20.59-82.93)$ & $(23.93-71.43)$ & $(47.06-62.95)$ \\
\hline \multirow{2}{*}{ Silt \%* } & $31.25 \pm 4.15^{\mathrm{a}}$ & $42.57 \pm 2.59^{\mathrm{b}}$ & $37.00 \pm 1.18^{\mathrm{a}}$ \\
\hline & $(9.75-76.47)$ & $(23.68-71.43)$ & $(28.71-44.75)$ \\
\hline \multirow{2}{*}{ Clay \%* } & $7.73 \pm 0.78^{\mathrm{a}}$ & $4.68 \pm 0.62^{\mathrm{b}}$ & $8.79 \pm 0.89^{\mathrm{a}}$ \\
\hline & $(2.5-13.79)$ & $(0.00-9.59)$ & $(2.67-16.89)$ \\
\hline \multirow{2}{*}{ Penetrability $(\mathrm{cm})^{*}$} & $4.53 \pm 0.26^{\mathrm{a}}$ & $11.62 \pm 0.53^{\mathrm{b}}$ & $9.39 \pm 0.55^{\mathcal{c}}$ \\
\hline & $(3.16-7.54)$ & $(8.32-15.14)$ & $(5.48-13.56)$ \\
\hline \multirow{2}{*}{ Redox layer length $(\mathrm{cm})^{*}$} & $6.20 \pm 0.40^{\mathrm{a}}$ & $1.30 \pm 0.157^{\mathrm{b}}$ & $2.91 \pm 0.30^{c}$ \\
\hline & $(2.62-9.68)$ & $(0.00-2.92)$ & $(0.86-4.76)$ \\
\hline
\end{tabular}

Note. Values are mean \pm SE, range in parenthesis. Different superscript letters in a row denote significant differences $(P<0.05)$ indicated by Tukey’s pairwise significant difference test. * indicates significantly calculated $P$ value detected by ANOVA.

redox depth leading to anoxic hostile conditions. As was discussed earlier, this is clearly the reason why the middle Avicennia zone had not any infaunal species.

Studies conducted by Hettiarachchi [40] and Chathurangi [41] on the spatial variation of macrobenthic fauna in Negombo estuary have shown a large number of infaunal taxa in the sedimentary environment of the open estuary. For example, Hettiarachchi [40] recorded that there were 32 infaunal taxa in the open estuary sediment near the Kadolkele mangrove forest. The true estuarine infaunal taxa prefer to live within the mud rather than on the substratum [42] perhaps in order to overcome the high fish predation coming along the overlying water column. In contrast to Hettiarachchi [40] and Chathurangi [41], however, the present study was carried out within the close by semiterrestrial mangrove environment where the fish predation is zero. Yet the infaunal species richness, diversity, and abundance in this mangrove benthic environment were found to be very low. This may be due to the harsh environmental conditions prevailing within the mangrove sedimentary environment as described above.

In contrast to infauna, the epifaunal taxa, however, were more abundant in the Kadolkele mangrove forest. The epifaunal community was mainly dominated by the surface deposit feeders such as molluscs and crustaceans. For example, the crabs, E. versicolor and S. guttatum, and the snails, Cassidula sp. and Melampus sp., were abundant both in the Lumnitzera and Avicennia zones. These species are restricted to the above zones as they prefer low salinity ranges [16]. When in danger molluscs in particular find refuge by withdrawing themselves into their shells while the crustaceans (crabs) easily find escape by moving into their or nearby burrows. These behaviours provide an added advantage for their survival, particularly from surface predation [43].

Further, these species shred mangrove leaf litter into small organic particles for their consumption, so that the food is readily available for them in these mangrove zones. Crabs and molluscs can also easily find refuges along the mangrove stems, seedlings, and roots from the incoming tide. This was observed at the field where molluscs are seen climbing up the mangrove tree trunks and on pencil roots while crabs running to elevated locations on the ground during the high tide. These factors directly influence on the increased diversity and abundance of epifauna of these molluscs and crustaceans in the Kadolkele mangrove forest. Therefore, the ability to protect from predation and the presence of an inexhaustible supply of mangrove leaf litter as organic food may have helped these epibenthic molluscs and crustaceans to increase their abundance on the surface.

The snails, Cassidula sp. and Melampus sp., were recorded in the present study as well. It was also found that these two species were restricted only to the Rhizophora zone. It was interesting to observe that these two species immediately climb down from the tree trunks to the mangrove floor for feeding when the ebb tide starts and again climb back when the next tide starts. This tree climbing behaviour has been observed by Shokita [44] as well. This is a good indication that the soil moisture/tide controls the distribution and abundance of some benthic fauna in mangrove forests. These two species have been identified as pollution indicator species by Kumar and Khan [6] as well. 
Even though the infaunal predation was low, the surface predation is high in the Kadolkele mangrove forest. For example, water monitors were seen roaming in the forest and some birds of prey were also seen perching on the mangrove forest floor. As a common response to avoid predation, these epifaunal species are highly camouflaged in the environment [45] in which crabs are coloured dark brown and black while molluscs are seen in shades of brown that suit the substrate they inhibit. Thus, it was observed that almost all the epifaunal taxa found in the Kadolkele Mangrove forest were highly camouflaged. It is also interesting to note here that there were many birds in the upper mangrove canopy, but they do not get an opportunity to prey on these epibenthic species very often. Perhaps the thick mangrove canopy and the aerial root structures obstruct them from immediate landing to catch these species.

Overall, the epifaunal diversity was high in the Rhizophora zone. As it is the zone at the land water interface, true estuarine species may find this zone a better refuge from the open estuary. Availability of detritus food and also the adequate safety can be the factors that govern the high number of epifaunal diversity in this Rhizophora zone.

During the study every effort was taken to minimize the seasonal variation, if any, on the benthic fauna. This was minimized to a greater extent by collecting samples from within all the 3 zones on days where the sampling was carried out.

The Kadolkele mangrove forest is already under pressure by many anthropogenic activities. The biggest challenge is the pollution taking place by domestic waste. For example, it was observed that the tides bring the nondegradable waste such as polythene and plastics into the mangrove forest and there they get entangled among the mangrove roots. The above wastes have spread in a vast area on the forest and removal of them may be very costly because the tides continually bring these wastes back again and again into the forest. Pilling up polythene, plastic materials, and other waste products on soil affect the burrowing animals such as crabs. It also reduces the scenic beauty of the forest.

The present study highlighted some aspects of ecology and the role of physicochemical parameters in sediment in structuring the macrobenthic community in the Kadolkele mangrove forest in Negombo estuary. The infaunal community structure was less diverse than the epifaunal community mainly due to the harshness of the sediment caused by the wide variation of physicochemical parameters in sediment and also by the structure of the associated mangrove vegetation.

\section{Conflict of Interests}

The authors declare that there is no conflict of interests regarding the publication of this paper.

\section{References}

[1] K. Kathiresan and L. Bingham, "Biology of mangroves and mangrove ecosystems," in Advances in Marine Biology, vol. 40, pp. 82-251, 2001.
[2] P. Doydee, D. Doungnamol, and W. Jaitrong, "Soil properties in the Ranong mangrove ecosystem, Ranong Province, Thailand," The Thailand National History Museum Journal, vol. 4, no. 2, pp. 63-70, 2010.

[3] L. Pinto, Mangroves of Sri Lanka, Natural Resources Energy \& Science Authority of Sri Lanka, 1986.

[4] S. Cannicci, F. Bartolini, G. Penha-Lopes, S. Fratini, M. Fusi, and F. Dahdouh-Guebas, Functions of macrobenthos in mangrove forests: >20 years of research lessons, 2012, http://www.vliz.be/ imisdocs/publications/243885.pdf.

[5] D. E. Roberts, Spatial Patterns in the Macrobenthic Fauna of Mangrove Forests in the Brisbane Water Estuary, Bio Analysis Pty Ltd: Marine estuarine Freshwater Ecology, 2006.

[6] P. S. Kumar and A. B. Khan, "The distribution and diversity of benthic macroinvertebrate fauna in Pondicherry mangroves, India," Aquatic Biosystems, vol. 9, no. 1, article 15, 2013.

[7] B. Thilagavathi, D. Varadharajan, A. Babu, J. Manoharan, S. Vijayalakshmi, and T. Balasubramanian, "Distribution and diversity of macrobenthos in different mangrove ecosystems of Tamil Nadu coast, India," Journal of Aquaculture Research and Development, vol. 4, no. 6, Article ID 1000199, 2013.

[8] M. Keshavarz, E. Kamrani, and A. R. Dabbagh, "A description of higher macrobenthic infaunal taxa of mangrove mud flats at Khamir Port, Iran," Annals of Biological Research, vol. 3, no. 2, pp. 1029-1043, 2012.

[9] D. M. Alongi and P. Christoffersen, "Benthic infauna and organism-sediment relations in a shallow, tropical coastal area: influence of outwelled mangrove detritus and physical disturbance," Marine Ecology Progress Series, vol. 81, no. 3, pp. 229245, 1992.

[10] A. M. Ellison, "Managing mangroves with benthic biodiversity in mind: moving beyond roving banditry," Journal of Sea Research, vol. 59, no. 1-2, pp. 2-15, 2008.

[11] S. Y. Lee, "Mangrove macrobenthos: assemblages, services, and linkages," Journal of Sea Research, vol. 59, no. 1-2, pp. 16-29, 2008.

[12] H. Joshi and M. Ghose, "Forest structure and species distribution along soil salinity and $\mathrm{pH}$ gradient in mangrove swamps of the Sundarbans," Tropical Ecology, vol. 44, no. 2, pp. 195-204, 2003.

[13] S. Matthijs, J. Tack, D. van Speybroeck, and N. Koedam, "Mangrove species zonation and soil redox state, sulphide concentration and salinity in Gazi Bay (Kenya), a preliminary study," Mangroves and Salt Marshes, vol. 3, no. 4, pp. 243-249, 1999.

[14] A. Safahieh, M. B. Nabavi, A. Vazirizadeh, M. T. Ronagh, and R. Kamalifar, "Horizontal zonation in macrofauna community of Bardestan mangrove Creek, Persian Gulf," World Journal of Fish and Marine Sciences, vol. 4, no. 2, pp. 142-149, 2012.

[15] I. Nagelkerken, S. J. M. Blaber, S. Bouillon et al., "The habitat function of mangroves for terrestrial and marine fauna: a review," Aquatic Botany, vol. 89, no. 2, pp. 155-185, 2008.

[16] S. H. R. Priyadarshani, S. C. Jayamanne, and Y. N. Hirimuthugoda, "Diversity of Mangrove crabs in Kadolkele, Negombo estuary, Sri Lanka, Sri Lanka," Journal of Fisheries and Aquatic Resources, vol. 13, pp. 109-121, 2008.

[17] K. A. R. S. Perera, M. D. J. S. Saparamadu, and M. D. Amarasinghe, "Net photosynthetic production and potential carbon assimilation capacity of mangroves of Kadolkele in Negombo estuary, Sri Lanka," in Proceedings of the 12th Annual Research Symposium, p. 113, University of Kelaniya, 2011. 
[18] National Wetland Directory of Sri Lanka, The Central Environmental Authority (CEA), International Union for Conservation of Nature and Natural Resources (IUCN) and the International Water Management Institute (IWMI), 2006.

[19] M. de Silva and P. K. de Silva, "Status, diversity and conservation of the mangrove forests of Sri Lanka," Journal of South Asian Natural History, vol. 3, no. 1, pp. 79-102, 1998.

[20] D. D. G. L. Dahanayaka and W. A. Sumanadasa, "Floral composition and vegetation structure of NARA mangrove reserve, Kadolkele, Sri Lanka and guidelines for conservation," in Proceedings of the International Forestry and Environment Symposium, pp. 25-26, Department of Forestry and Environment Science, University of Sri Jayewardenepura, Nugegoda, Sri Lanka, 2007.

[21] M. Fernando, Shells of the Sri Lanka Seashore, Biodiversity Secretariat, Ministry of Environment, 2009.

[22] L. Williams, Environmental Chemistry, A Modular Approach, John Wiley \& Sons, Chichester, UK, 2001.

[23] N. C. Brady and R. R. Weil, The Nature and Properties of Soil, Prentice Hall, Englewood Cliffs, NJ, USA, 12th edition, 1999.

[24] M. L. Jackson, Soil Chemical Analysis, Prentice Hall of India, New Delhi, India, 1978.

[25] C. H. Fernando and A. S. Mendis, A Guide to the Freshwater Fauna of Ceylon (Sri Lanka), Fisheries Research Station, Ceylon, Sri Lanka, 1962.

[26] T. G. Pillai, "Annelida Polychaeta from the Philippines and Indonesia," Ceylon Journal of Science (Biological Sciences), vol. 5, no. 2, pp. 110-175, 1965.

[27] M. Quigley, Invertebrates of Streams and Rivers: A Key to Identification, Edward Arnold, London, UK, 1977.

[28] K. Fauchald, The Polychaete Worms. Definitions and Keys to the Orders, Families and Genera, Natural History Museum of Los Angeles Country, 1977.

[29] H. Nesemann, G. Sharma, and R. K. Sinha, "Aquatic Annelida (Polychaeta, Oligochaeta, Hirudinea) of the Ganga River and adjacent water bodies in Patna (India: Bihar), with description of a new leech species (Family Salifidae)," Annalen des Naturhistorischen Museums in Wien, vol. 105, pp. 139-187, 2004.

[30] A. E. Magurran, Ecological Diversity and It's Measurements, Princeton University Press, Princeton, NJ, USA, 1st edition, 1988.

[31] S. Melles, S. Glenn, and K. Martin, "Urban bird diversity and landscape complexity: species-environment associations along a multiscale habitat gradient," Conservation Ecology, vol. 7, no. 1, 5 pages, 2003.

[32] J. M. A. L. Jayakody, M. D. Amarasinghe, V. Pahalawattaarachchi, and K. H. W. L. de Silva, "Vegetation structure and potential gross primary productivity of mangroves at Kadolkele in Meegamuwa (Negombo) estuary, Sri Lanka," Sri Lanka Journal of Fisheries and Aquatic resources, vol. 13, pp. 95-108, 2008.

[33] M. D. Amarasinghe, "Ecological functions of mangrove and related ecosystems and their contribution to economic sustainability," Sri Lanka Journal of Aquatic Sciences, vol. 2, pp. 1-20, 1997.

[34] M. D. Amarasinghe, J. A. Liyanage, and K. G. S. Nirbadha, "Presence of heavy metals in lands of a tropical freshwater wetland in Sri Lanka as an indicator of their relative phytoremediation potential for heavy metal contaminated water from urban runoff," in Proceedings of the 2nd World Conference on Environmental Management, J. M. Jahi, K. Arifin, S. Surif, and S.
Idrus, Eds., pp. 311-319, Universiti Kebangsaan Malaysia, Bangi, Malaysia, 2004.

[35] A. Gayathri, "Life at the margins: the social, economic and ecological importance of mangroves," Madera y Bosques, pp. 5360, 2002.

[36] V. Pahalawattaarachchi and M. D. Amarasinghe, "Leaf litter decomposition and changes in leaf $\mathrm{C}: \mathrm{N}$ ratio in the mangals of Negombo lagoon (Sri Lanka)," Sri Lanka Journal of Aquatic Sciences, vol. 2, pp. 29-42, 1997.

[37] T. J. Smith, "Mangrove forest structure," in Mangrove Ecology: A Manual for a Field Course, I. C. Feller and M. Sitnik, Eds., Smithsonian Institution, Washington, DC, USA, 1996.

[38] R. Reef, I. C. Feller, and C. E. Lovelock, "Nutrition of mangroves," Tree Physiology, vol. 30, no. 9, pp. 1148-1160, 2010.

[39] C. K. Yap, A. Rahimismail, M. Z. Azrina, A. Ismail, and S. G. Tan, "The influential of physico-chemical parameters on the distributions of oligochateas (Limnodrilus sp.) at the polluted downstream of the tropical Langat River," Journal of Applied Sciences and Environmental Management, vol. 10, no. 3, pp. 135140, 2006.

[40] A. Hettiarachchi, Spatial variation of macrobenthic fauna in some selected sites in Negombo estuary in relation to prevailing physico chemical parameters in the environment [B.Sc. Special degree dissertation], University of Kelaniya, Colombo, Sri Lanka, 2010.

[41] N. G. M. Chathurangi, The role of physico-chemical characteristics and density of the seagrass cover on the spatial distribution of macrobenthic community in the Negombo estuary [Special Degree Dissertation], University of Kelaniya, Colombo, Sri Lanka, 2011.

[42] W. H. Wilson, "Competition and predation in marine softsediment communities," Annual Review of Ecology and Systematics, vol. 21, no. 1, pp. 221-241, 1990.

[43] P. Hutchlings, “The fauna of Mangroves,” 2000, http://ojs.library .unsw.edu.au/index.php/wetlands/article/view/109/133.

[44] S. Shokita, "The role of aquatic animals in mangrove ecosystems," in Mangrove Management and Conservation, M. Vannucci, Ed., pp. 76-110, United Nations University, New York, NY, USA, 2004.

[45] T. Detto, J. M. Hemmi, and P. R. Y. Backwell, "Colouration and colour changes of the fiddler crab, Uca capricornis: a descriptive study," PLoS ONE, vol. 3, no. 2, Article ID e1629, 2008. 

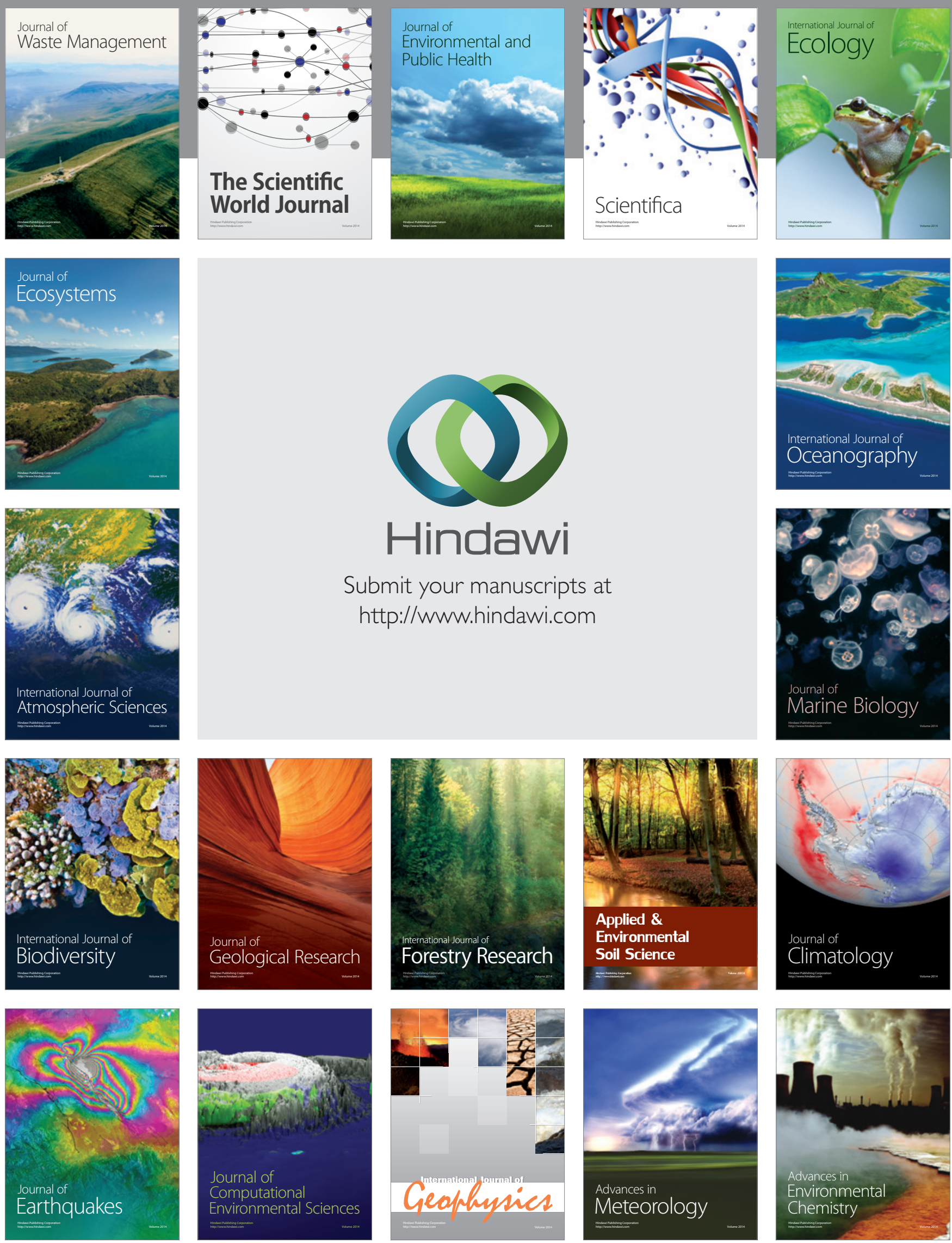